\title{
STUDIES ON THE LEPROMIN TEST
}

\section{The Third Report. RELATION BETWEEN THE LEPROMIN REAGTION AND THE TUBERGULIN REACTION}

\author{
Ken YANAGISAWA et al \\ (National Institute of Health) \\ Toshiyasu SAITO et al \\ (Sanitarium Section, Medical Affairs Division, Welfare Ministry) \\ Yoshinobu HAYASHI et al \\ (Tama Zenshoen) \\ Shigetaka TAKASHIMA et al \\ (Suruga-Leprosarium) \\ Ryoichi YAJIMA et al \\ (Kuryu Rakusenen) \\ Kensuke MITSUDA et al \\ (Nagashima Aiseien) \\ Ryoichi JINGU et al \\ (Oku Komyoen) \\ Taiji NOJIMA et al \\ (Oshima Seishoen)
}

In order to analyze the relation between the lepromin reaction and the tuberculin reaction, both animal experiments and investigations in human bodies were conducted.

The results were obtained as follows.

1) In the guinea pigs injected with tubercle bacilli or BCG the tuberculin and lepromin reactivity appeared at the same time.

2) In healthy human bodies which had ever received natural tuberculous infection or BCG vaccination, a high correlation was observed between the tuberculin and early lepromin reactions concerning the size of redness.

3) In leprous patints, however, such a correlation was scarcely observed regardless of the clinical type.

\section{Lepromin 反応に関寸る研究（第 3 報）}

\section{Lepromin 反応と Tuberculin 反応との関連性}

\author{
柳沢 兴・浅見 望・前田道明 \\ （国立予防衛生研究所）

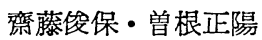 \\ （厚生省医務局療養所課） \\ 林 芳信・義汇義雄 - 田尻 敢・稲葉俊雄・立川 昇 \\ (多磨全生園) \\ 高島重孝・石原重徳・馬場省二・中村喜和・ 小城英男 \\ (駿河療養所) \\ 矢嶋良一・後藤貞夫・小林茂信・本荘賢司・寺角正二・野上秀夫 \\ （栗生楽泉園） \\ 光田健輔・宮田唯夫・桜井方策・塩沼英之助・伊東正保・名和千嘉・永田まる・横田篤三 \\ 犀川一夫・鈴木正和・日比久子
}




\section{（長島愛生園） \\ 神宮良一・難波政士・戸田円二郎 \\ (邑久光明園)}

野島泰治・守屋睦夫・高橋竹代・尾崎嘉厚・宇都宫貞俊・井口己広・古賀敬一 （大島青松園）

（昭和 30 年 9 月 1 日 受稿)

緒論

1939年 Fernandez ${ }^{(1)}$ が Lepromin 反心と Tuberculin 反 応との関連性について研究してから, 多くの研究者 ${ }^{(2)}-$ (12) がこれに関する研究を行つた。従来の研究成果を総 合してみると，健康者及び瀨を合併しない結核患者を対 象とした場合には Lopromin 反応と Tuberculin 反応との 間には密接な関係があつて, 結核菌と癩菌との間には共 通抗原があるかの如くみえる。とれに反して，瘾患者に 於ける Lepromin 反応と Tuberculin 反応との間には病型 の如何に拘らず，非瀨者の如き密接な関係がなさそらで ある。

私達はとのような Lepromin 反応と Tuberculin 反応と の関連性の重要なととに鑑み，これに関する動物実験並 びに人体に於ける観察を詳細に行つた。

\section{I 動 物 実 験}

\section{実験方法}

実験動物としては約 $300 \mathrm{~g} \sim 1000 \mathrm{~g}$ のモルモットを使用 し，その第 I群は健唐末感作モルモット6匹，第 II群は BCG 30mg を筋肉内に接種して 2 カ月を経過したモルモ ット 6 亿, 第吕群は有毒結核菌青山 B 株死菌 $6 \mathrm{mg}$ を 0.5 cc の流動 Paraffin に浮游せしめたものを筋肉内に接種 して10カ月を経過したモルモット6匹である。とれらの
各モルモットの背部の毛を丁寧に拔き, 光田抗原, Dharmendra 抗原（との両抗原は第 1 報に述べたものと同一 のものである) Tuberculin 2,000 倍希勫液（国立予防衛 生研究所製標準 Tuberculin) 及び対照液として $0.5 \%$ 石 炭酸加生理的食塩水の 4 種の液をそれぞれ 0.1cc ずつ皮 内に注射する。即ち 1 匹のモルモットの背部正中線の左 右に対象的に光田抗原と Dharmendra 抗原, Tuberculin 希橎液と対照液とを注射した。注射後 4，10，24，34， 48 及び 72 時間, 更に 1 週後及び 2 週後の各反応を観察 計測する。モルモットでは発赤の大きさと硬結の大きさ とは略々等しいので，硬結の大きさ（短径と長径との算 術平均値）を以て反応の大きさとした。な打各群 6 匹の 平均値を以て各群を代表せしめた。

\section{実験成績及びその考察}

第I群の未感作モルモットに於ける光田抗原, Dharmendra 抗原, Tuberculin 希橎液及び対照液の注射局所反応 の経過は第 1 図に示す如く，いずれの抗原にこ於いても注 射後 10 時間が最も反応が大きく以後次第:こ消退する。

但し，反応の最も大きいのは光田抗原でするけれど も，8mm を超えず，非特異性反応と思われる。光田抗 原による反応以外は 48 時間以内で消失, 光田抗 原と雖 も 1 週間以内には消失する。乙れに反して，BCGで感作 された第II群モルモットでは第 2 図に示すように，注射

第1図 未感作モルモットに対し光田及び Dharmendra 抗原，並びにTuberculin 及び 対照液注射後における反応の時間的推移

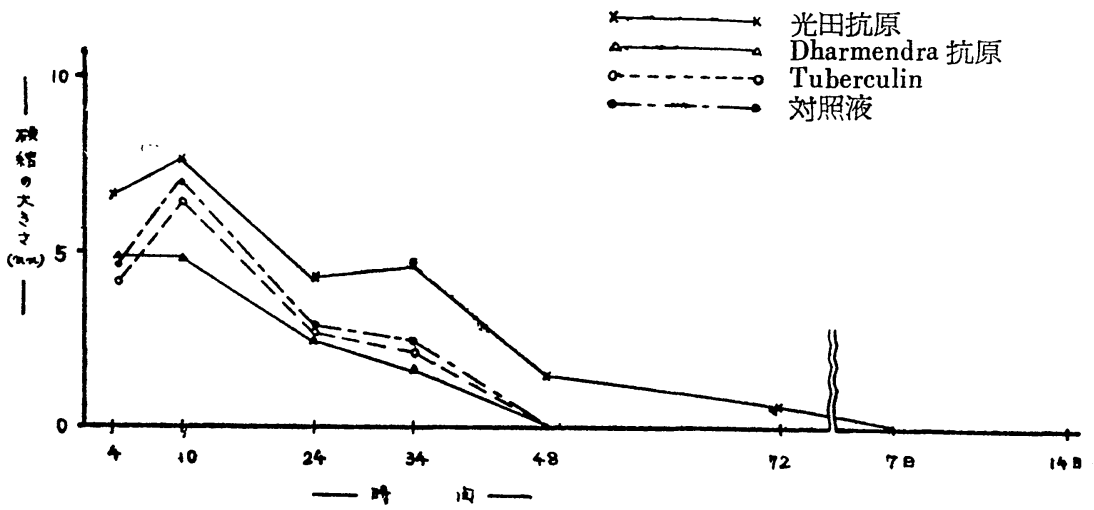


第 2 図 BCG 感作モルモットに対し光田及び Dharmendra 抗原, 並びに Tuberculin 及び対照液注射後に打ける反応の時間的推移

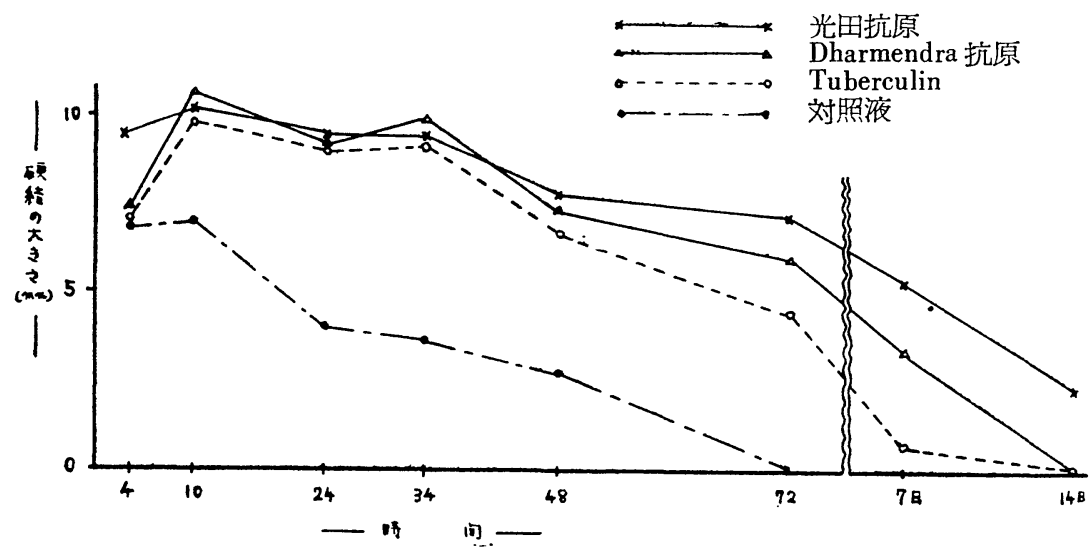

第 3 図人型結核菌感作モルモットに対し, 光田及びDharmendra 抗原. 並びに

Tuberculin 及び対照液注射後に括ける反応の時間的推移

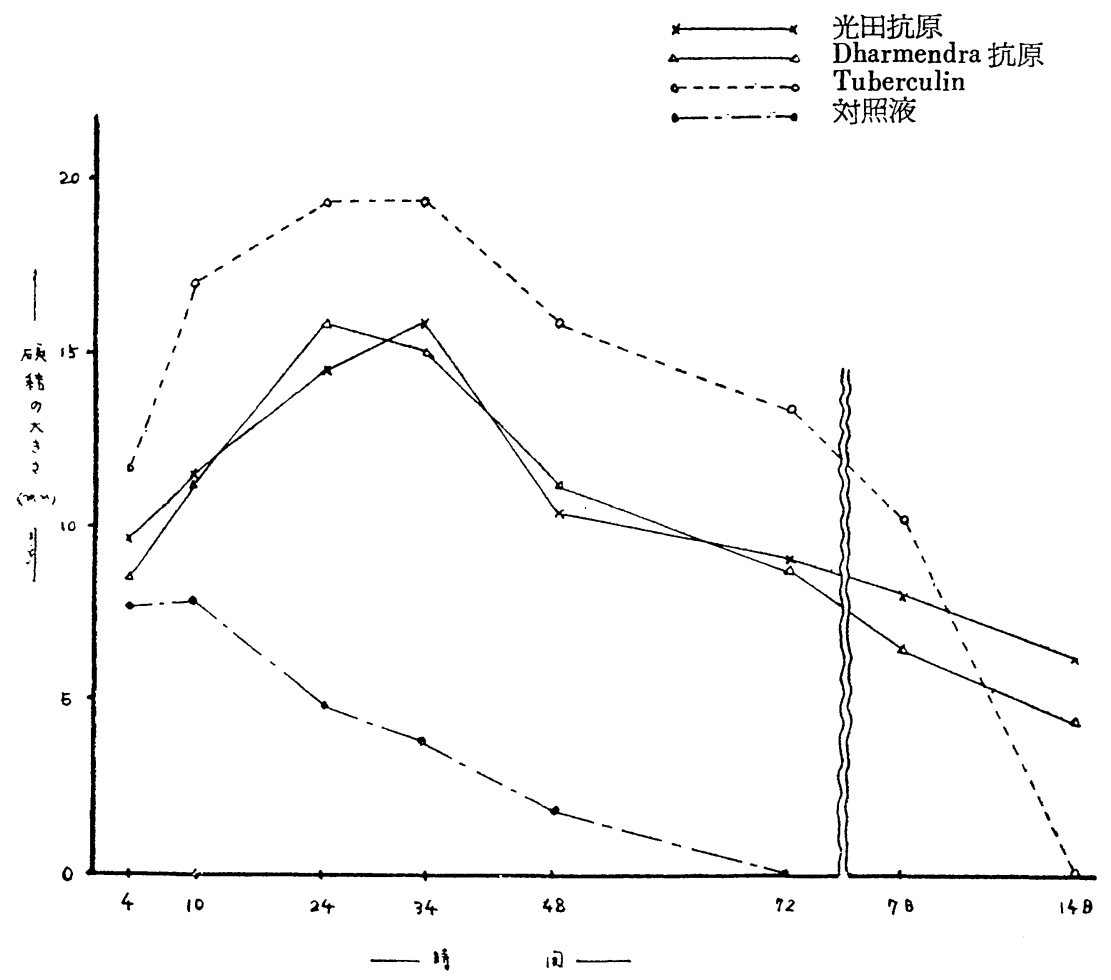

後 10 時間にして 3 抗原はいずれも反応の大きさ $10 \mathrm{~mm}$ 前後になり，との大きさは 34 時間位まで続き 以後は次 第に小さくなり, Dharmendra 抗原及び Tuberculin は 2 週後には反忘か殆んど消退する。しかし，光田抗原では な颃小さい硬結をのとす。BCG 感作モルモットでは光 田抗原, Dharmendra 抗原及び Tuberculin 希液の注射
局所反応は注射後 2 週以内では，ほぼ同等の大きさで経 過する点は Chaussinand ${ }^{(6)}$ 及び Castro(10) のモルモット に於ける実験成績と軌を一にする。

更に，有毒結核菌によつて感作した第亚群モルモット の成績は第 3 困に示すように，光田，Dharmendra 抗原 及び Tuberculin 希橎液に対して，注射後 24 時間より 34 
時間に於いて強い反応を呈し, 以後次第に消退してゆ く。Tuberculin 希釉液と光田及び Dharmendra 抗原との 区応を比較すれば BCG 感作の場合とちがい Tuberculin 希粎液が遙かに強い反応を呈する。

第II群及び第吕群に於ける Tuberculin 希釈液及び光 田, Dharmendra 両抗原に対する反心はいずれる 特異性 区応でめつて, 抗原抗体反応に属するアレルギー反応と 考えられるものである。

\section{II 人体に於ける研究}

Lepromin 反応と Tuberculin 反応との関連性をみるた めに人体を対象として行つた私達の研究を 3 つに分けて 述べるととする。

その 1 つは無瀨地域（non-leprous area）に於ける健康 者, 即ち癩未感染者が対象でめり, 他の 2 つは瀨患者が 対象である。

A）無瀬地域に於ける健康者（瀬未感染者）について の研究

\section{研究方法}

1）対象：無㸊地域と思われる某村小中学校生徒が主 なる対象である。対象者 245 名は結核の自然感染者 54 名 （BCG 接種を受けたことなしに Tubeculin 反応が陽性
なものである。但してのうちには結核患者は 1 人も含ま れていない）と BCG 既接種者 191 名である。BCG 接種 後自然感染を受けたものは 191 名中に含まれていても極 めて少数と推定される。

2) Dharmendra 抗原希粎液: Dharmendra 抗原は第 1 報に述べたすのと同一のものであるからことでは製法は 省略する。但し，この健度者に注射した Dharmendra抗 原希䍐液は原液を $0.5 \%$ 石岸酸加生理的食塩水で 3 倍に 希粏したものである。

3） Tuberculin 希粎液：Tuberculin 原液を $0.5 \%$ 石崖 酸加生理的食塩水で 2,000 倍に希粎したるのである。

4）注射方法と判定方法：右側前膊屈側には Tuberculin 希彩夜を, 左側前膊屈側には Dharmendra 抗原希

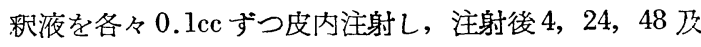
び 72 時間に於いて反応の大きさを計測した。反応は発 赤の大きさと硬結の大きさとを区別して計測したが，硬 結の大きさの計測の困難な場合もあつたので, 専ら発赤 の大きさで検討した。

\section{研究成績及びその考察}

瀨未感染健康者を結核自然感染者と BCG 既接種者に 分けて，注射後 $4,24,48$ 及び 72 時間に於ける発赤の 大きさの平均值を追跡すると第 4 図の如くなる。

第 4 図 瀨未感染者に於ける Tuberculin (OTI：2000) 反伈及び Dharmendra の時間的推移

T: O. T.

D: Dharmendra 抗原

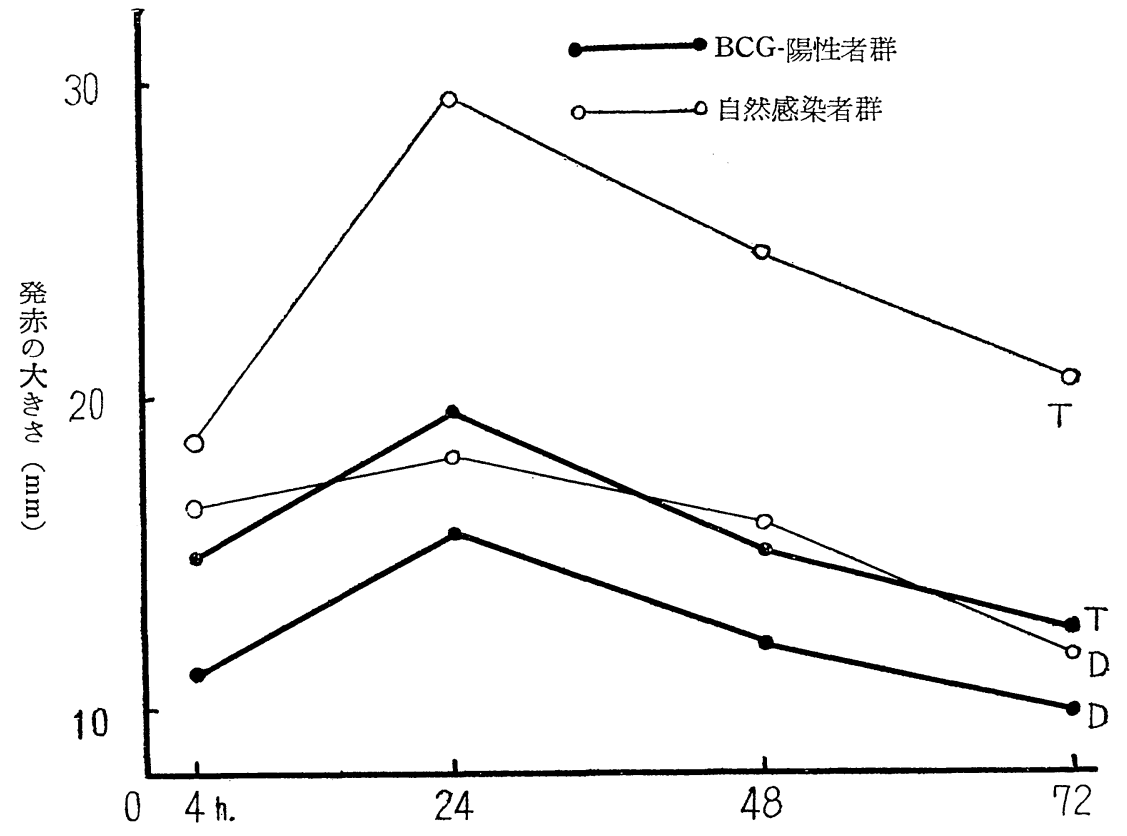


第 1 表 瀨未感染者に怙ける Tuberculin 及び Dharmendra 抗原注射後 48 時間発赤值の相関表

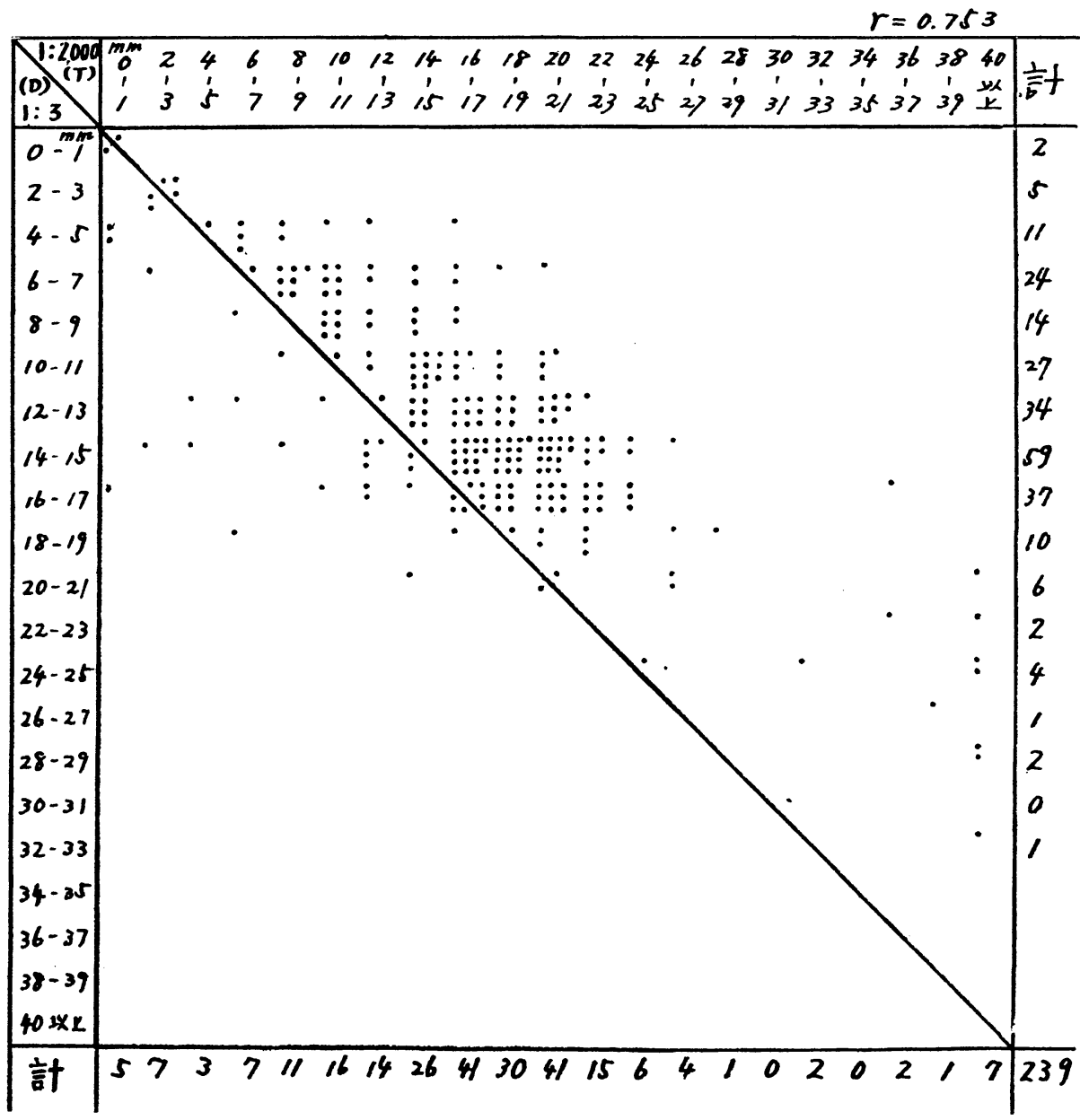

即ち，両群とも注射後24時間に於いて最高值を示し， 漸次消退する。また，自然感染者群はBCG 既接種者群 よりも，Lepromin 反応に扎いても，Tuberculin 反応に 顿いても，判定時の如何を問わず大きな反応を呈し，且 つ両反応は大体に打いて平行的に消長するようでめる。

更に，両反応の関連性を精細に観察するため，非特異 性の殆んど消退したと思われる注射後 38 時間に於ける 両反忍の発赤の大きさの相関表を作つてみると，第 1 表 る如く，Lepromin 反応は Tuberculin 反応よりも発赤は 総体的に小さいけれどす, 可成りよく相関するととがわ かる。即ち，相関係数を算出するに $\gamma=0.753$ となる。

以上のととから結核菌文は BCG によつて感作された 人体に颃いては Lepromin 反応もその個体 の Tuberculin 反応の大きさに相応して発現するよらに思われる。また 両反応は, その硬結の触知, 二重発赤の有無, 色調の濃
淡などあらゆる点で極めて類似した様相を呈する。即 ち, 人体に於いても, モルモットに於けると同様に, 結 核個体に於ける Lepromin 反応及び Tuberculin 反応は48 時間を中心とする早期反态では，濃度の異つた同一抗原 による反応と云つてもよい位である。との点については 既に多くの研究者が認めているととろであつて, 私達は 両反応の関連性をやや扱い方をかえて観察したに過ぎな wo

B）瀨患者についての研究(1)

研究方法

1) 対象：Lepromin 反応と Tuberculin 反応との比較 対象は瀨患者 2912 名（結節型 2119 名, 神玟型 793 名） である。

2）光田抗原及び Dharmendra 抗原：第 1 報に述べた とてろと同一のものであるからととでは製法は省略す 
第 2 表 結節型瀬患者に於ける光田抗原による Lepromin 早期反応と Tuberculin 反応 $(1: 2000)$ との相関

発赤の大きさ $(\mathrm{mm})$

$\gamma=0,399$

\begin{tabular}{|c|c|c|c|c|c|c|c|c|c|c|c|c|c|c|c|c|c|c|c|c|}
\hline $\mathrm{T}$ & $0 \sim 1$ & & $34 \sim 5$ & & $3 \sim 9$ & 10 & 1 & $\tilde{15}$ & 516 & $7, \quad 1$ & & 2123 & $\tilde{c}^{24} \widetilde{25}$ & 27 & 29 & 931 & 33 & 3 & $42 \widetilde{43}$ & Tota \\
\hline $0 \sim 1$ & & & & & & & & & & & & & & & & & & & & \\
\hline $2 \sim 3$ & 1 & 11 & 7 & 5 & 1 & & 1 & & & & & 1 & & 1 & & & & & & 28 \\
\hline $4 \sim 5$ & 4 & 4 & 23 & 5 & & & & & & & & & & & & & & & & 36 \\
\hline $6 \sim 7$ & 6 & 12 & 14 & 7 & 2 & & 1 & & 1 & & & & & 3 & & & & & & 46 \\
\hline $8 \sim 9$ & 3 & 3 & 21 & 6 & 1 & 1 & 1 & & $!$ & & 2 & 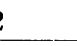 & & & & & & & & 38 \\
\hline $10 \sim 11$ & 18 & 33 & 42 & 22 & 8 & 3 & 3 & 2 & & 2 & 3 & 3 & & 1 & & & & & & 137 \\
\hline $12 \sim 13$ & 30 & 52 & 70 & 43 & 9 & 8 & 5 & 3 & 5 & 2 & 3 & 1 & 3 & & & & & & & 234 \\
\hline $14 \sim 15$ & 54 & 60 & 112 & 55 & 17 & 4 & 7 & 5 & 4 & 2 & & 3 & & 1 & 1 & & & 1 & & 326 \\
\hline $16 \sim 17$ & 47 & 42 & 109 & 57 & 24 & 10 & 7 & 7 & 2 & 3 & 1 & 2 & 1 & & 1 & 2 & & & & 315 \\
\hline $18 \sim 19$ & 43 & 44 & 78 & 51 & 20 & 6 & 8 & 2 & 5 & 7 & 2 & & 2 & 1 & & & & & & 269 \\
\hline $20 \sim 21$ & 35. & 27 & 88 & 56 & 25 & 13 & 13 & 10 & 8 & 6 & 5 & 4 & 1 & & & & & $!$ & & 291 \\
\hline $22 \sim 23$ & 22 & 17 & 49 & 27 & 12 & 6 & 6 & 5 & 3 & 2 & 2 & 1 & 1 & 1 & 2 & & & & & 156 \\
\hline $24 \sim 25$ & 15 & 11 & 16 & 16 & 7 & 6 & 4 & 3 & 4 & 2 & 1 & & & & & & 1 & & 1 & 84 \\
\hline $26 \sim 27$ & 5 & 7 & 14 & 4 & 9 & 2 & 1 & & 2 & 2 & 1 & 1 & & & & & & & & 48 \\
\hline $28 \sim 29$ & 4 & 2 & 4 & 2 & 2 & 3 & 2 & 2 & 1 & & & & 1 & & & & & & 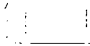 & 23 \\
\hline $30 \sim 31$ & 4 & 6 & 2 & 2 & 1 & 1 & & & & 1 & & & & & & & & & & 17 \\
\hline $32 \sim 33$ & 1 & 4 & 1 & 1 & 1 & 1 & & 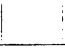 & & 1 & 1 & & $!$ & & & & & I & & 11 \\
\hline $34 \sim 35$ & 2 & 2 & 1 & 4 & & & 1 & 1 & & $! 1$ & 1 & & & & & & & & & 13 \\
\hline $36 \sim 37$ & 1 & & & & 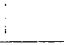 & & . & 1 & & 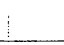 & & & & & & & & & & 2 \\
\hline$\sim 39$ & 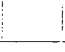 & & 2 & & 1 & & 1 & & & $!$ & 1 & & & & & & & & & 5 \\
\hline $40 \sim 41$ & & 2 & 1 & 2 & & & 2 & & & 1 & 2 & & & & & & & & & 10 \\
\hline $42 \sim 43$ & 1 & & 2 & 1 & & & & & & 1 & 1 & & 1 & & & & & & & 7 \\
\hline $44 \sim 45$ & 1 & & 1 & & & : & 1 & & 1 & 1 & & ! & & & & & & & & 5 \\
\hline $46 \sim 47$ & & 1 & & & & 1 & & & & & & 1 & & & & & & & & 3 \\
\hline $48 \sim 49$ & & 1 & 1 & & & & 1 & & & & & 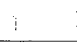 & & & & & & & & 3 \\
\hline $50 \sim 51$ & 1 & & & & 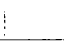 & & & & & & & $\vdots$ & & & & & & & & 1 \\
\hline $52 \sim 53$ & & & & 1 & & & & & & 1 & & & i & i & & & & & & 2 \\
\hline $54 \sim 55$ & & & & & & & & & & 1 & & & & & & & & & & 1 \\
\hline $56 \sim 57$ & & & & & & & 1 & & & $\vdots$ & & & & & & & & & & 1 \\
\hline $58 \sim 59$ & & & & & & & & & & 1 & & & & & & & & & & 0 \\
\hline $60 \sim 61$ & 1 & & & 1 & & 1 & & 1 & 2 & & & & 1 & & & & & & & 7 \\
\hline Total & 296 & 341 & 658 & 368 & 140 & 66 & 66 & 42 & 38 & 36 & 26 & 14 & 11 & 8 & 4 & 2 & 1 & 1 & 1 & 2119 \\
\hline
\end{tabular}

る。

3） Tuberculin 希勫液：A）に抢いて述べたすのと同 様である。

4) 注射方法と判定方法

光田抗原及び Dharmendra 抗原は右側及び左側前膊屈 側に，Tuberculin 希䣋液は上膊内側に注射し，注射後
48 時間に於ける発赤の大きさを比較の対象とした。 研究成績及びその考察

1）結節型攋患者に於ける 光田抗原による Lepromin 早期反応と Tuberculin 反応との相関

第 2 表にみる如く相関々係は極めて低く，その相関係 
第 3 表 神経型獺患者に於ける光田抗原による Lepromin 早期反応と Tuberculin 反応 $(1: 2000)$ との相関

発赤の大きさ $(\mathrm{mm})$

\begin{tabular}{|c|c|c|c|c|c|c|c|c|c|c|c|c|c|c|c|c|c|c|c|c|c|c|c|c|c|c|c|}
\hline $\begin{array}{ll} & M \\
T & \\
T\end{array}$ & $\begin{array}{l}0 \\
? \\
1\end{array}$ & $\begin{array}{l}2 \\
? \\
3\end{array}$ & $\begin{array}{l}4 \\
? \\
5\end{array}$ & $\begin{array}{l}6 \\
? \\
7 \\
\end{array}$ & $\begin{array}{l}8 \\
? \\
9\end{array}$ & $\begin{array}{c}10 \\
? \\
11\end{array}$ & \begin{tabular}{|c|}
12 \\
1 \\
13 \\
\end{tabular} & $\begin{array}{c}14 \\
? \\
15\end{array}$ & \begin{tabular}{|c|}
16 \\
1 \\
17
\end{tabular} & $\begin{array}{c}18 \\
? \\
19 \\
\end{array}$ & $\begin{array}{c}20 \\
2 \\
21\end{array}$ & $\begin{array}{c}22 \\
? \\
23\end{array}$ & $\mid \begin{array}{c}24 \\
1 \\
25\end{array}$ & \begin{tabular}{|c|}
26 \\
1 \\
27 \\
\end{tabular} & \begin{tabular}{|c|}
28 \\
$?$ \\
29 \\
\end{tabular} & \begin{tabular}{|c|}
30 \\
2 \\
31 \\
\end{tabular} & $\mid \begin{array}{c}32 \\
1 \\
33\end{array}$ & \begin{tabular}{|c|}
34 \\
2 \\
35
\end{tabular} & $\left|\begin{array}{c}36 \\
2 \\
37\end{array}\right|$ & \begin{tabular}{|c|}
38 \\
2 \\
39 \\
\end{tabular} & \begin{tabular}{|c|c|}
40 & 4 \\
$l$ & \\
41 & 4 \\
\end{tabular} & \begin{tabular}{c|c}
42 & \\
2 & \\
43 & \\
\end{tabular} & \begin{tabular}{|c|c|}
44 & 4 \\
$?$ & \\
45 & 4 \\
\end{tabular} & $\begin{array}{c}46 \\
2 \\
47\end{array}$ & $\begin{array}{c}48 \\
2 \\
49 \\
\end{array}$ & \begin{tabular}{|c|}
50 \\
$?$ \\
51
\end{tabular} & Total \\
\hline $0 \sim 1$ & 1 & 6 & 5 & 6 & 3 & 3 & 5 & 4 & 6 & 5 & 4 & 4 & & 2 & 1 & & & & & & & & & & & & 55 \\
\hline $2 \sim 3$ & 1 & 1 & 1 & 1 & & & 1 & 1 & & 1 & & 1 & & 1 & & & & & & & & & & & & & 9 \\
\hline $4 \sim 5$ & 1 & & 4 & & & & & & 1 & 2 & 1 & & 2 & & 1 & & & & & & & & & & & & 12 \\
\hline $6 \sim 7$ & 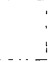 & 3 & & 1 & & & 2 & 1 & 1 & 2 & 1 & 1 & 1 & & 1 & & & & & & & & & & & & 14 \\
\hline $8 \sim 9$ & 1 & 1 & 6 & 1 & & & & & 3 & 2 & 4 & 2 & 2 & 1 & & & & & & & & & & & & & 23 \\
\hline $10 \sim 11$ & 4 & 1 & 3 & & 1 & 5 & 1 & 3 & 6 & 2 & 4 & 7 & 4 & 2 & & & & & & & & & 1 & & & & 44 \\
\hline $12 \sim 13$ & 3 & 2 & 9 & 4 & 4 & & 4 & 6 & 13 & 8 & 11 & 9 & 7 & 2 & & & 1 & & & & & & & & & & 83 \\
\hline $14 \sim 15$ & & 7 & 12 & 6 & 2 & 2 & 3 & 11 & 14 & 4 & 16 & 9 & 6 & 2 & 1 & 1 & & 2 & & & & & & & & & 98 \\
\hline $16 \sim 17$ & 6 & 2 & 3 & 2 & 3 & 6 & 2 & 5 & 6 & 13 & 15 & $19^{\prime}$ & 8 & 7 & 3 & 1 & 1 & 1 & & & & & 1 & & & I & 105 \\
\hline $18 \sim 19$ & 3 & 4 & 3 & & 2 & 6 & 6 & 5 & 9 & 12 & 14 & 17 & 6 & 10 & 5 & 5 & & 1 & & & 1 & & & 1 & & & 110 \\
\hline $20 \sim 21$ & 3 & 8 & 5 & 1 & & 3 & 5 & 11 & 7 & 10 & 15 & 11 & 8 & 4 & 3 & 4 & 1 & 1 & & 1 & & & 1 & & & & 102 \\
\hline $22 \sim 23$ & 2 & 1 & & 3 & & 1 & 6 & 5 & 9 & 3 & 4 & 11 & 5 & 7 & 5 & 2 & & & & & & & & & & & 64 \\
\hline $24 \sim 25$ & & 2 & 1 & 1 & & 2 & 1 & 3 & 6 & 2 & $3:$ & 4 & 4 & $2^{i}$ & 1 & 1 & & & & & & 1 & & & & & 34 \\
\hline $26 \sim 27$ & & & & & 1 & & & & 1 & 1 & 2 & 1 & & & 2 & 1 & & & & & & & & & & ; & 9 \\
\hline $28 \sim 29$ & & & 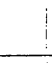 & & & 1 & & & & 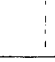 & 1 & 1 & & 1 & & 1 & & & & & & & & 1 & & & 6 \\
\hline $30 \sim 31$ & 1 & 1 & & & & 1 & & & 1 & 1 & 1 & 1 & 1 & & 1 & & & & & & & & & 1 & & & 10 \\
\hline $32 \sim 33$ & & & & : & & & & & & & 1 & & & & & 1 & & & & & & & & & & & 3 \\
\hline $34 \sim 35$ & & & & & & & & & & 2 & 2 & & 1 & & 1 & & & & & & & & & & & & 6 \\
\hline $36 \sim 37$ & & & & & & & & & & & & 1 & & & & & & & & & ! & & & | & & & 1 \\
\hline $38 \sim 39$ & & & & & & & & & & & & & 1 & & & & & & & & & & & & & & 1 \\
\hline $40 \sim 41$ & & & & & & & & & & 1 & & 1 & & & & & 1 & & & & & & & & & & 3 \\
\hline $42 \sim 43$ & & & & & & & & & & & & & & & & & & & & & & & & & & & \\
\hline $58 \sim 59$ & & & & & & & & 1 & & & & & & & & & & & & & & & & & & & 1 \\
\hline Total & 26 & 39 & 52 & 26 & 16 & 30 & 36 & 56 & 83 & 71 & 99 & 100 & 056 & 41 & 26 & 17 & 4 & 5 & & 1 & 1 & 1 & 3 & 3 & & 1 & 793 \\
\hline
\end{tabular}

数は 0.399 である。

2）神経型賴患者に於ける光田抗原による Lepromin 早期反応と Tuberculin 反応との相関

第 3 表にみる如く, この場合も相関々係は低く, 相関 係数は 0.242 である。
また，結節型及び 神経型 癩忠 者中 Lepromin 反応 る Tuberculin 反応す共に陽性のもの, 両反応の相関をみる に，乙の場合も極めて低く，相関係数は -0.0025 であ る。

な抢, 光田抗原による Lepromin 晚期反心之 Tubercu 
第 4表 結節型瀨患者に於ける Dharmendra 抗原による Lepromin 早期反心と Tuberculin 反応 $(1: 2000)$ との相関

発赤の大きさ $(\mathrm{mm})$

$\mathrm{r}=0.141$

\begin{tabular}{|c|c|c|c|c|c|c|c|c|c|c|c|c|c|c|c|c|c|c|c|c|c|}
\hline $\mathrm{T}$ & $0 \sim 1$ & $2 \sim 3$ & $4 \sim 5$ & $6 \sim 7$ & $8 \sim 9$ & $10 \sim$ & $12 \sim$ & $3^{14} \sim$ & $15{ }^{16}$ & $-17{ }^{1}$ & $18 \sim$ & $9 \stackrel{20}{21}$ & $122 \widetilde{23}$ & & $|26 \sim 27|$ & $7]^{28} 2$ & $\begin{array}{c}30 \\
9\end{array}$ & 31 & $\tilde{3}^{34}$ & 5 & Total \\
\hline $0 \sim 1$ & & & & & & & & & & & & & & & & & & & & & \\
\hline $2 \sim 3$ & 5 & 9 & 6 & 4 & & & 1 & & & & 1 & & & & 1 & . & 1 & 1 & & & 28 \\
\hline $4 \sim 5$ & 11 & 15 & 5 & 3 & 2 & & & & & & & & & & & & ! & & & & 36 \\
\hline $6 \sim 7$ & 13 & 7 & 17 & 3 & 2 & & & & & 1 & & & 1 & 1 & & & & & 1 & & 46 \\
\hline $8 \sim 9$ & 9 & 8 & 13 & 3 & 2 & 1 & & 1 & 1 & & & 1 & & & & $:$ & & & & & 38 \\
\hline $10 \sim 11$ & 43 & 46 & 26 & 4 & 3 & 3 & 4 & 3 & 3 & 2 & 1 & 2 & & & & & & & & & 137 \\
\hline $12 \sim 13$ & 55 & 74 & 56 & 17 & 8 & 3 & 6 & 4 & 4 & 4 & 1 & 3 & & 21 & & & & & & & 234 \\
\hline $14 \sim 15$ & 93 & 93 & 65 & 33 & 8 & 5 & 5 & 9 & 9 & 5 & 4 & 3 & 2 & 2 & & 1 & & & & & 326 \\
\hline $16 \sim 17$ & 82 & 70 & 73 & 39 & 12 & 7 & 12 & 6 & 6 & 7 & 2 & & & $2 \quad 1$ & 1 & & & & 1 & & 315 \\
\hline $18 \sim 19$ & 69 & 66 & 56 & 28 & 16 & 9 & 6 & 7 & 7 & 2 & 6 & 1 & 1 & $1 \quad 2$ & & & & & & & 269 \\
\hline $20 \sim 21$ & 71 & 52 & 77 & 27 & 20 & 8 & 9 & 11 & & 4 & 4 & 2 & & $\begin{array}{ll}1 \quad 2 \\
\end{array}$ & 1 & 1 & 1 & 1 & & & 291 \\
\hline $22 \sim 23$ & 46 & 21 & 35 & 15 & 11 & 4 & 7 & 8 & 8 & 1 & 2 & 1 & & 1 & 1 & & 2 & 2 & & 1 & 156 \\
\hline $24 \sim 25$ & 20 & 14 & 12 & 13 & 7 & 5 & 4 & 4 & 4 & $1 !$ & 1 & & & $: \quad 1$ & & 1 & & 1 & 1 & & 84 \\
\hline $26 \sim 27$ & 12 & 9 & 9 & 4 & 5 & 4 & 1 & & & 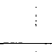 & 3 & 2 & 1 & 1 & & & & &.$i$ & & 48 \\
\hline $28 \sim 29$ & 5 & 3 & 6 & 1 & 3 & 1 & & & & 1 & 1 & & 2 & 2 & & & & & $\vdots$ & & 23 \\
\hline $30 \sim 31$ & 6 & 2 & 3 & 2 & & 1 & 2 & 1 & 1 & & & $i$ & $!$ & & & & - & $i$ & & & 17 \\
\hline $32 \sim 33$ & 1 & 2 & 3 & 4 & & & & 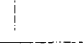 & 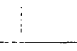 & & 1 & & & $:$ & & & 1 & & & & 11 \\
\hline $34 \sim 35$ & 3 & 3 & 1 & 2 & 2 & 1 & & 1 & $\vdots$ & 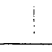 & & 1 & & 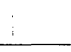 & & & 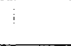 & & & & 13 \\
\hline $36 \sim 37$ & 1 & 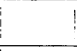 & 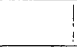 & & & & & $i$ & $1^{1}$ & 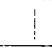 & & & & i & & : & & & : & & 2 \\
\hline $38 \sim 39$ & 1 & & 3 & & & & 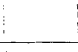 & 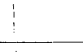 & $\vdots$ & $\vdots$ & & i & 1 & 1 & & & & & & & 5 \\
\hline $40 \sim 41$ & 3 & 1 & 3 & & 1 & & 2 & & 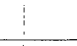 & 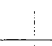 & & & & & & . & & & & & 10 \\
\hline $42 \sim 43$ & & 1 & & & 2 & 1 & & & 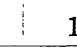 & 1 & 1 & & & 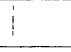 & & i & 1 & $L$ & & & 7 \\
\hline $44 \sim 45$ & 2 & 1 & 1 & 1 & & & & $\vdots$ & i & & & & & : & & & & & & & 5 \\
\hline $46 \sim 47$ & & & & & 2 & & & & $\vdots$ & & & & 1 & 1 & & & & & : & & 3 \\
\hline $48 \sim 49$ & 1 & & 2 & & & & & & i & 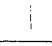 & & & & & & & & & & & 3 \\
\hline $50 \sim 51$ & 1 & & & & & & & 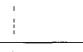 & $!$ & $!$ & & & 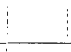 & 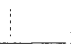 & & & & & & & 1 \\
\hline $52 \sim 53$ & & & & & & 2 & & & 1 & & & & & : & & & & & & & 2 \\
\hline $54 \sim 55$ & & & & & & & & & & & 1 & & & & & & & & & & 1 \\
\hline $56 \sim 57$ & & & & & & & & 1 & 1 & $\vdots$ & & & & & & & & 1 & & & 1 \\
\hline $58 \sim 59$ & & & & & & & & & I & & & & & $\vdots$ & & & & & & & \\
\hline $60 \sim 61$ & 2 & & & 1 & & 2 & & 1 & 1 & & & & & 1 & & & & & & & 7 \\
\hline Total & 555 & 497 & 427 & 204 & 104 & 57 & 59 & 57 & 29 & 9 & 29 & 16 & 15 & 9 & 4 & 3 & 5 & 3 & 3 & 1 & 2119 \\
\hline
\end{tabular}

lin 反応との相関も極めて低いととは，第 1 報でのべた 光田抗原による早期反応と晩期反応との高い相関から推 知されよう。

3）結節型瀨患者に於けるDharmendra 抗原による Lepromin 早期反応と Tuberculin 反応との相関 第 4 表に示す如く，相関係数は 0.141 で低い相関と云わ
ねばならない。

4）神経型滇患者に於ける Dharmendra 抗原による Lepromin 早期反応と Tuberculin 反忍との相関

第 5 表に示す如く，相関係数は 0.164 で相関は極女てて 低い。

更に，両刑に属する瀨患者中 Lepromin 反忘すTuber- 
第 5 表 神経型瀨患者に於ける Dharmendra 抗原による Lepromin 早期反匛と Tuberculin 反応 $(1: 2000)$ との相関

発赤の大きさ $(\mathrm{mm})$

\begin{tabular}{|c|c|c|c|c|c|c|c|c|c|c|c|c|c|c|c|c|c|c|c|c|c|c|c|c|}
\hline $\mathrm{T}^{\mathrm{D}}$ & $\begin{array}{l}0 \\
? \\
1 \\
\end{array}$ & $\begin{array}{l}2 \\
? \\
3\end{array}$ & $\begin{array}{l}4 \\
? \\
5 \\
\end{array}$ & $\begin{array}{l}6 \\
? \\
7\end{array}$ & $\begin{array}{l}8 \\
? \\
9\end{array}$ & $\mid \begin{array}{c}10 \\
? \\
11\end{array}$ & $\begin{array}{c}12 \\
? \\
13\end{array}$ & \begin{tabular}{|c|}
14 \\
2 \\
15 \\
\end{tabular} & \begin{tabular}{|c|}
16 \\
2 \\
17 \\
\end{tabular} & \begin{tabular}{|c|}
18 \\
2 \\
19 \\
\end{tabular} & $\mid \begin{array}{c}20 \\
2 \\
21\end{array}$ & \begin{tabular}{|c|}
22 \\
1 \\
23 \\
\end{tabular} & \begin{tabular}{|c|}
24 \\
2 \\
25 \\
\end{tabular} & \begin{tabular}{|c|}
26 \\
2 \\
27
\end{tabular} & \begin{tabular}{|c|}
28 \\
$?$ \\
29 \\
\end{tabular} & \begin{tabular}{|c|}
30 \\
2 \\
31
\end{tabular} & \begin{tabular}{|c|}
32 \\
2 \\
33
\end{tabular} & $\begin{array}{c}34 \\
2 \\
35\end{array}$ & $\begin{array}{c}36 \\
? \\
37\end{array}$ & \begin{tabular}{|c|}
38 \\
$?$ \\
39
\end{tabular} & $\begin{array}{c}40 \\
\text { ? } \\
41\end{array}$ & \begin{tabular}{|c|}
42 \\
2 \\
43 \\
\end{tabular} & \begin{tabular}{|c|c|}
44 & 46 \\
2 & 2 \\
45 & 47 \\
\end{tabular} & Total \\
\hline $0 \sim 1$ & 2 & 4 & 5 & 3 & 3 & 2 & 2 & 7 & 2 & 10 & 8 & 3 & 1 & 1 & 2 & & & & & & & & & 55 \\
\hline $2 \sim 3$ & 2 & & 2 & & & & & 1 & 1 & 1 & & 1 & & & 1 & & & & & & & & & 9 \\
\hline $4 \sim 5$ & & & 2 & 2 & & & & 1 & & & 1 & 2 & 1 & & 1 & 1 & & & & & & & 1 & 12 \\
\hline $6 \sim 7$ & 1 & 2 & & 1 & & & 1 & 1 & 4 & 2 & 2 & & & & & & & & & & & & & 14 \\
\hline $8 \sim 9$ & 4 & 1 & 1 & 1 & & 2 & & 1 & 3 & 2 & 3 & 1 & 2 & 1 & & 1 & & & & & & & & 23 \\
\hline $10 \sim 11$ & 2 & 3 & 2 & & 1 & 1 & 1 & 5 & 5 & 5 & 6 & 2 & 5 & 3 & 2 & & & & & & 1 & & & 44 \\
\hline $12 \sim 13$ & 7 & 1 & 7 & & 1 & & 4 & 3 & 9 & 12 & 18 & 10 & 6 & 2 & 2 & 1 & & & & & & & & 83 \\
\hline $14 \sim 15$ & 7 & 8 & 4 & 7 & & 2 & 6 & 6 & 4 & 11 & 15 & 10 & 10 & 4 & 2 & 1 & & 1 & & & & & & 98 \\
\hline $16 \sim 17$ & 4 & 4 & 6 & 2 & 2 & 4 & 5 & 5 & 12 & 9 & 16 & 12 & 8 & 9 & 1 & 2 & 3 & & & & 1 & & & 105 \\
\hline $18 \sim 19$ & 4 & 4 & 8 & 2 & 1 & 2 & 7 & 6 & 7 & 11 & 15 & 16 & 5 & 8 & 7 & 3 & 1 & 3 & & & & & & 110 \\
\hline $20 \sim 21$ & 1 & 2 & 10 & 5 & 5 & 6 & 7 & 3 & 3 & 13 & 13 & 10 & 10 & 7 & 5 & 1 & & 1 & & & & & & 102 \\
\hline $22 \sim 23$ & 2 & 2 & & 2 & 1 & 1 & 2 & 9 & 5 & 7 & 7 & 7 & 5 & 5 & 3 & 2 & & & & 1 & & & & 64 \\
\hline $24 \sim 25$ & 1 & 3 & 2 & & 2 & & & 3 & 4 & 3 & 2 & 5 & 2 & 3 & 2 & & 1 & 1 & & & & & & 34 \\
\hline $26 \sim 27$ & & & & & & & & 1 & 1 & 2 & 1 & 2 & 1 & & 1 & & & & & & & & & 9 \\
\hline $28 \sim 29$ & & & & & & & & 1 & & & 1 & 2 & 1 & & 1 & & & & & & & & & 6 \\
\hline $30 \sim 31$ & & & 1 & & & & & & 2 & & 1 & 3 & & 1 & & & & & 1 & & & 1 & & 10 \\
\hline $32 \sim 33$ & & & & & & & & & 1 & & & & & 1 & & 1 & & & & & & & & 3 \\
\hline $34 \sim 35$ & & & & & & & & & 1 & & 3 & & & 1 & 1 & & & & & & & & & 6 \\
\hline $36 \sim 37$ & & & . & 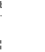 & & & & & 1 & & & & & & & & & & & & & & & 1 \\
\hline $38 \sim 39$ & & & 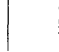 & ! & & & & & & : & ! & & & 1 & & & & & & & & & $\vdots$ & 1 \\
\hline $40 \sim 41$ & & & & & & & 1 & & & & & 1 & & & & & 1 & & & & & & & 3 \\
\hline & & & 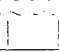 & 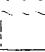 & & & 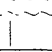 & & I & & & & & & & & & & & & & & $i$ & \\
\hline $60 \sim 61$ & & & & & & & 1 & & & & & & & & & & & & & & & & i & 1 \\
\hline Total & 37 & 34 & 53 & 25 & 16 & 20 & 37 & 53 & 65 & 88 & 112 & 87 & 57 & 47 & 31 & 13 & 6 & 6 & 1 & 1 & 2 & 1 & $: 1$ & 793 \\
\hline
\end{tabular}

culin 反応も陽性のものについての両反応の 相関係数を

算出すると 0.046 である。

以上から明かなように Dharmendra 抗原による場合も 光田抗原による場合と同様に，Lepromin 反応と Tuberculin 反応との相関は殆んどないと云つてもよい程でめ る。

また，結節瀨患者の Tuberculin 陽性率は 85.0\% 神経
型患者のそれは $83.1 \%$ で両型間には有意の差がない。

然し, 瀨患者の Tuberculin 反応陽性者の大多数は二 重発赤と硬結とを有する強反応を呈する点は，現在無癩 地域の反応の集団の検査では見られないところである。 これは結核の濃厚頻回感染のためか，或いは結核と瀨と の合併感染によるためか, 或いは瀨の発症するような素 質のものには結核感染により特に強いアレルギーが発生 
第6表 攋患者に於ける Dharmendra 抗原による Lepromin 早期反応と Tuberculin 反忍 $(1: 20000)$ との相関

発赤の大きさ $(\mathrm{mm})$

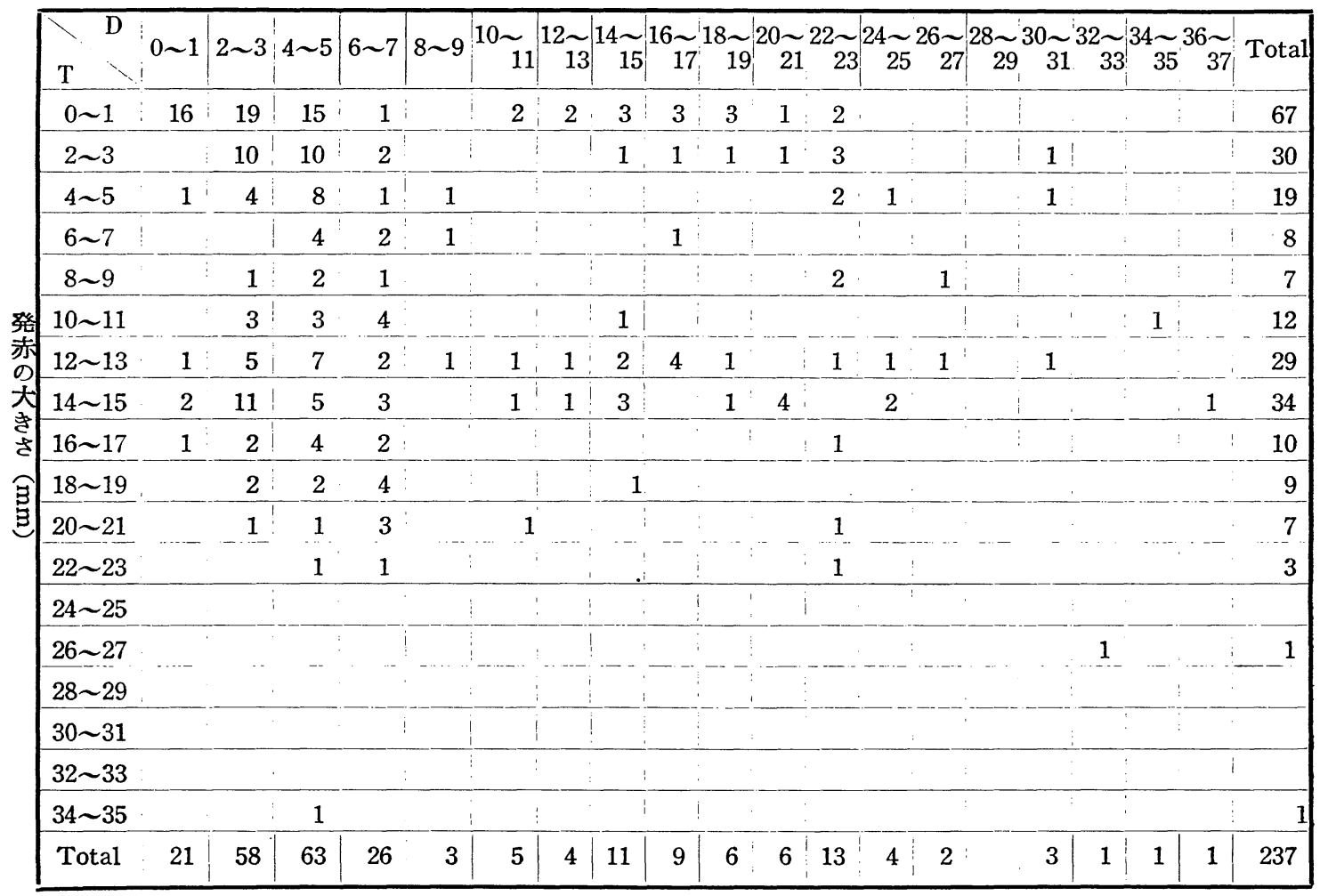

するものであろらか, 直ちには決定し難い。今後の研究 に俟たねばならない。

\section{C) 瀨患者についての研究(2)}

この研究は前述の癩患者に於いて Tuberculin 反忍が 余りに强く出現したので, そのために Lepromin 反応と の相関が低くなつたのではないかを疑い，との研究では 顆患者237名を対象として左側前膊屈側にはDharmendra 抗原を, 右側前膊屈側には Tuberculin 20000 倍希鄱液を 注射し, 注射後 48 時間に於ける両反応 の発赤の大きさ の相関をみるに, 第6表に示すよ5に, 矢張り低い相関 々係があるに過ざず，相関係数は 0.292 ですつた。

上に述べた動物実験及び人体研究に於いて健康動物及 は人体は結核菌で感作することによつて Lepromin 反応 が陽転する場合が多く, 且つ, Tuberculin 反応の大きさ と反応の大きさとはよく相関するに反し，瀨患者の場合 には Lepromin 反応と Tuberculin 反応とは殆んど無関係 の如く生起するととを確め得た。この機序については全 く不明であるが癩のアレルギーと免疫とを論ずる上には 極めて興味ある事実であつて, 今後の研究を期待すべき
でむる。

結 論

1）結核菌又はBCGを接種したモルモットでは Tuberculin 反応が陽転すると同時に Lepromin 早期反応す 陽転する。

2）結核の自然感染又は BCG 接種を受けた 健䐂者に 於いても Tuberculin 反応の大きさLepromin と早期反応 の大きさとの間には高い相関々係がある。

3）しかるに, 瀨患者に於いては, その病型の如何を 問わず, Tuberculin 反応の大きさと Lepromin 反応の大 きさとの間には殆んど関係がないよらでむる。

稿を終るにむたり, 多額の研究費を御贈与下さいまし た藤楓協会に哚甚なる謝意を表します。なお, 終始, 熱 心なる御激励を研究現場に打いて打与え下さいました同 協会浜野常務理事に対し㳭謝いたします。

参考交献

1) Fernandez, J. M. M. : Estudio comparativo de la 
reacción de Mitsuda con las reacciones tuberculinicas Rev. argentina Dermatosif, 23, 21 (1939)

2) 前田ティ: BCG 注射の小児 Mantoux 及び光田反忘 に及ぼす影響。レプラ, 11, 104, (1940)

3 ) Fernandez, J. M. M.: Influence del factor tuberulosis sobre la reaccion a la lepromina, Rev. Argentinanorteamericana Cien. Méd, 1, 592 (1943)

4) Gines, A.R. and Poletti, J. G. : La reaccion de Mitsuda en los vacunados con BCG (Posibilidades de la vacunacio BCG en la profilaxia de la lepra), Hoja Tisiol, 5, 284 (1945); also An. Fac. Cien. Med. Asuncion, 5, 101 (1945)

5 ) Chaussinand, R.: Para-allergies bacteriennes dans la tuberculose, Ann. Inst. Pasteur, 73, 814 (1947)

6) Chaussinand, R.: La reaction de Mitsuda, indice de I'immunite relative antilepreuse, Mem. V Congr. Internac. Lepra, Havana 1948 ; Havana 1949, 595.

7) Azulay, R. D. : A ação do B.C. G. Sobre a reação leprominica. Mem. V. Congr. Internac. Lepra, Havana, 1948 ; Havana, 1949, 1142
$8)$ Floch, H. and Destombes, P. : Allergie et paraallergie dans la lépre. Reaction de Mitsuda; Allergie lèpreuse et allergie tuberculoide; Vaccination par le B. C. G., Internat. J. Leprosy, 18, 177 (1950)

9 ) Rosemberg, J., Souza Campos, N. and Aun, J. N. : Da relacāo imunobiológica entre tuberculose e lepra. I. ação positivante do B.C. G. sobre a lepromino-reaação. Rev. brasileira Leprol, 18, 3 (1950)

10) Olmos Castro, N.: Sensitization to lepromin induced experimentally with B. C. G., Internat. J. Leprosy, 20, 221 (1952)

11) Convit, J. and Rassi, E. : Lepromin and tuberculin test in venezuelan leprosy foci, induction of lepromin, reactivity by B. C. G. vaccination, Internat. J. Leprosy' 22, 303 (1954)

12) Guinto, R.S ., Doull, J. A. and Maralay, E. B. : Tuberculization and reactivity to lepromin. association between lepromin and tuberculin reactions in school children in Cordova and Opon Cebu, Philippines Internat. J. Leprosy, 23, 32 (1955) 